Article

\title{
An Empirical Analysis of Mode Choice Decision for Utilitarian and Hedonic Trips: Evidence from Iran
}

\author{
Enayat Mirzaei ${ }^{1, *}$ and Dominique Mignot $^{2}$ (D) \\ 1 Faculty of Urban Planning, Lorestan University, Khoramabad 68151-44316, Iran \\ 2 Department of Transport Health Safety, University Gustave Eiffel, 69675 Bron, France; \\ dominique.mignot@univ-eiffel.fr \\ * Correspondence: mirzaei.e@lu.ac.ir; Tel.: +98-066-3312-0097
}

Citation: Mirzaei, E.; Mignot, D. An Empirical Analysis of Mode Choice Decision for Utilitarian and Hedonic Trips: Evidence from Iran. Sustainability 2021, 13, 6896. https:// doi.org/10.3390/su13126896

Academic Editors: Peter Nijkamp, Karima Kourtit and Marina Toger

Received: 29 March 2021

Accepted: 4 May 2021

Published: 18 June 2021

Publisher's Note: MDPI stays neutral with regard to jurisdictional claims in published maps and institutional affiliations.

Copyright: (c) 2021 by the authors. Licensee MDPI, Basel, Switzerland. This article is an open access article distributed under the terms and conditions of the Creative Commons Attribution (CC BY) license (https:/ / creativecommons.org/licenses/by/ $4.0 /)$.
Abstract: A sizeable body of literature reveals a strong relationship between mode choice and health status. Therefore, society would benefit from travel if transportation and urban planners motivated more individuals to satisfy their desire for travel by active transportation rather than motorized transportation. Despite rich existing literature about the relations between the built environment and travel, we still need to address some research gaps in explaining travel mode choice. As a shortcoming, identifying and measuring the primary motivations for trips, and then incorporating such motivations into travel mode choice modelling, has received less attention in previous research. In this regard the current paper follows two main goals. It aims to differentiate between trips by determining the main utility of travelers and then analyzes the impact of the built environment measurements and subjective attributes on mode choice decision. Using data from a survey of 515 participants who reside in Isfahan, Iran, we conducted a series of binary logistic models to explore how the built environment influences mode choice decisions for different trips, controlling for socio-economics and subjective attributes. The results show that the number of hedonic trips were sizably more than utilitarian trips. It was found that travel mode choice for utilitarian and hedonic trips is influenced by travel habits and subjective attitudes, but the built environment also matters. Specifically, two built environment characteristics, including density and diversity, can substitute walking/cycling for driving for utilitarian trips. In addition, car use for hedonic trips is not influenced by built environment measurements. It seems that the utility and desire of hedonic driving depends on mode of travel. It is concluded that driving and walking/biking for hedonic and utilitarian trips are not single behaviors and differentiating between trips according to their main utility and considering both objective and subjective attributes helps urban and transportation planners prescribe appropriate spatial and nonspatial strategies to encourage walking/biking.

Keywords: utilitarian and hedonic travel; built environment; subjective attributes; mode choice modelling; Iran

\section{Introduction}

During recent years, travel mode choice has received attention from the fields of urban and transport planning [1] and public health [2]. Increased sustainable transport modes for different types of trips could make an environment healthier and more cohesive by reducing traffic congestion, air pollution and emissions [3-5], improving public and private health [6-8] and increasing social unity and sense of place in neighborhoods [9,10]. Theoretically, smart growth, compact city, new urbanism and transit-oriented development as recent urban planning approaches have focused on sustainable travel mode choice. Empirically, a large body of studies have been carried out to investigate the impacts of different factors on mode choice. In spite of significant progress in this field, we still need to address some research gaps in explaining travel behavior. As an important shortcoming, eliciting primary motivations and utilities of trips, and then incorporating such motivations into travel behavior modelling, have received less attention in previous research. 
The majority of past studies chiefly assumed that travel is a derived demand. It means that people just travel to engage in activities which are distributed within an area [11,12]. It is fully agreed that this notion can truly explain the primary motivation of mandatory trips such as work, medical care and business trips [11,13]. Nevertheless, there are some other types of travel, including both directed trips (purposive) and undirected trips (see [13]). In these cases, travel has a positive intrinsic utility and is not just a means of reaching a destination. So, travel is not a disutility that should be minimized.

As a common classification in previous studies, trips have been classified into utilitarian and recreational travel. A few studies, directly concerning motivation of trips, classified the trips based on having a destination in mind or having no destination in mind [13-16]. These classifications can be challenged because the boundary of some trips or activities was blurred, and because of this ambiguity the characterization of some trips was inconsistence across studies [17]. In addition, individuals may have a specific destination for their trips but reaching the destination is not their primary motivation. According to Kang et al. [15], the lack of specificity in differentiating between trips with different motivations may contribute to weakening the estimation power of mode-choice models. The lack of a clear procedure, and a standard instrument to identify and measure trip motivations, may be chief challenges in differentiating between trips [18-20]. Therefore, a better understanding of primary motivation of trips is essential to prescribe policies more realistically.

Considering the aforementioned matters, the contribution of this study is as follows: (1) the study aims to make distinction between nonwork trips according to their main utility and then incorporates this primary utility to mode choice modeling; (2) this study attempts to capture any influence of subjective attitudes including lifestyle, travel attitudes and sense of place on an individuals' travel mode decision. These factors, especially sense of place, have received less attention in the literature compared to built environment attributes. (3) Most previous relevant studies were conducted in Europe, North America, and Australia, while research in a developing country, which has dissimilar social, cultural, and geographical situations, may disclose different results.

It worth noting that current research focused on nonworks trips, because these kinds of trips mainly do not have a mandatory nature and it is more likely that people start such trips for different utilities. It is hypothesized that it is more likely that nonutilitarian or hedonic travel is weakly affected by built environment factors, while utilitarian trips are strongly affected by built environment factors controlling for subjective variables including socio-economics, lifestyle, attitudes and sense of place.

\section{Literature}

From a theoretical standpoint, the literature, dating back approximately three decades, supports the intrinsic motivation of travel and provides important insights into this type of motivation. Jones [21] suggested that it is "more realistic to view destination choice process as an interactive trade-off between the positive and negative features of both travel and destination options". Hupkes [22] pointed out that that "the utility for travel has not only derived but intrinsic components ... which can be called intrinsic utility". Mokhtarian et al. [11] reviewed the earlier academic perspectives on the "positive utility of travel". Thus, if this kind of utility exists, it is important to better realize it and incorporate it into travel behavior modeling. Mokhtarian and Salomon [12] suggest three components of 'utility for travel': "the utility of activities conducted at the destination", "the utility of activities that can be conducted while traveling", and "the utility of activity of traveling itself". These aspects could theoretically be distinctive, but practically are complex and less easily measured. Derived demand theory simply explains the demand for travel based on the first aspect. The other elements refer to intrinsic and positive utility of travel [12,13]. It seems that derived travel is made due to the first affinity, and 'excess travel' is made due to the last two aspects of utility. Excess travel is specified as 'travel beyond that which is necessary to reach a destination' [12]. Therefore, for excess travel, individuals may take a longer route (or a more distant destination) and consequently spend more time and money. 
From an empirical standpoint, the French National Travel Survey of 2007 revealed that "the destination for the $15 \%$ of trips is not the only important thing and fewer than $3 \%$ of trips are promenade without precise destination" [14]. From "travel time" perspectives, Gripsrud and Hjorthol [23] supported the idea that travel time is not only a disutility, but can be useful and productive. Based on a household survey in the San Francisco Bay Area, Redmond and Mokhtarian [24] reported that ideal travel time for $98.8 \%$ of participants is nonzero. Redmond and Mokhtarian [24] showed that only 1.8\% of their sample stated an ideal commute time of less than four minutes. Based on a sample of 106 Lexington, Kentucky, Parkany et al. [25] found that one third of drivers chose paths which had a travel time at least $10 \%$ higher than the shortest routes. The ideal travel is an optimal travel time that comprises both of intrinsic and extrinsic utilities of travel [26].

A major challenge of typical transportation surveys is that they are not sensitive to intrinsic motivation of travel. This issue could be due to difficulty in assessing the extent to which a given trip is intrinsically or extrinsically motivated. Mokhtarian et al. [27] suggested applying "teleportation test" as an important modification to a standard travel/activity diary. The teleportation test is a helpful tactic to clarify between the mentioned utilities of travel [28]. The teleportation test is simply applied by this question: "If you could snap your fingers or blink your eyes and instantaneously teleport yourself to the desired destination, would you do so?" [11]. If participants clearly answered 'no' to the teleportation test, they would refer to the intrinsic utility of travel [28].

The other part of our interest in the current study is to develop the discussion on connection between the built environment, subjective attributes, and mode choice selection after controlling for socio-economic variables. The built environment has been mostly identified by density, diversity, design and transit accessibility [29]. Numerous studies from developing and developed countries argue that mode choice decisions are significantly affected by different built environment characteristics, and reveal almost similar results. The results of previous research on built environment and mode choice decisions, focusing on developing countries, are combined as follows. Much research found that density measurements (population and job density) are negatively associated with car use, and positively related to cycling, walking and public transit usage [30-41]. Indeed, previous research found that a higher degree of mixed land use reduced car use and encouraged nonmotorized travel modes [29,37,42-44]. The results argue that high density and diversity shorten distances between activities and support walking, and cycling, while decreasing car dependency $[35,39,45]$. However, some studies did not find significant impacts of mixed land use on travel mode choice $[45,46]$. As for design, previous studies mostly concluded that walking and biking are positively associated with network connectivity, block density and street and intersection density [29,39,47]. Nonetheless, Zhao [48] and Etminani-Ghasrodashti and Ardeshiri [43] mentioned that increase in roads density would decrease the probability of nonmotorized modes. Several studies found a significant negative linkage between walking/biking and distance to the Central Business District (CBD) $[49,50]$ and transit accessibility [50,51]. Transit accessibility was found to lower the probability of driving [52,53]. The meta-analysis study of Ewing \& Cervero [29] showed that intersection or street density most positively impacted, and land-use mix marginally impacted, on walking and transit mode choice. Surprisingly, they found population and job densities had a weak association with travel behavior.

Socio-demographics have often been considered in the relevant research. Regarding age, the results are mixed. Some studies found that older people walk more often and are less likely to drive $[16,54,55]$, but others reported reverse results $[43,56]$. Walking is generally found to be higher among women than men [55,57]. Car ownership, generally has a negative association with the probability of walking/cycling [57-59], whereas the bicycle ownership has a positive association with cycling [59-61]. Household size is often found to have a positive association with car ownership and car use, and a negative relationship with walking [41,54]. Much research has found that educational level, employment status or income are positively associated with car use and negatively related to walking/cycling [16,41,43,57]. 
The theoretical mechanism supporting these facts that lifestyle, attitudes, habit and sense of place impact on travel behavior is grounded in the theories of "value-beliefnorm theory" [62] and "planned behavior (TPB)" [63]. Lifestyle as behavioral patterns is "derived from underlying opinions and orientations, including beliefs, interests and attitudes" [64]. Therefore, lifestyles can be considered as general orientations to different subjects like leisure, work, family, consumption and housing [65]. Previous research, which incorporated the lifestyle concept in travel behavior models concluded that lifestyle significantly impacted on car availability, trip distance and trip frequency by different modes $[43,66]$. Etminani-Ghasrodashti and Ardeshiri, [43] found that the effects of lifestyle on travel behavior was stronger than the built environment. TPB theory claims that an individual's intention directly leads to performing a behavior [63]. The contribution of travel attitudes and perceptions of neighborhood characteristics in explaining travel behavior has been explained using TPB theory $[13,43,66-70]$. TPB has been criticized because it does not consider unconscious human behaviors [71]. In fact, individuals do not always behave consciously [72,73] and their behaviors are driven by unconscious processes. Therefore, other individual factors such as habits should be accounted for as well [67-70]. Hence, travel habits are taken into consideration in this study.

\section{Methodology}

\subsection{Data and Study Area}

Our data were collected through a survey conducted in 12 neighborhoods across Isfahan, Iran in 2018 (see Figure 1). Isfahan, as the largest city in the center of Iran (with 1.8 million people), has nearly a population density of 3734 persons per square kilometer and 534,256 households [74].

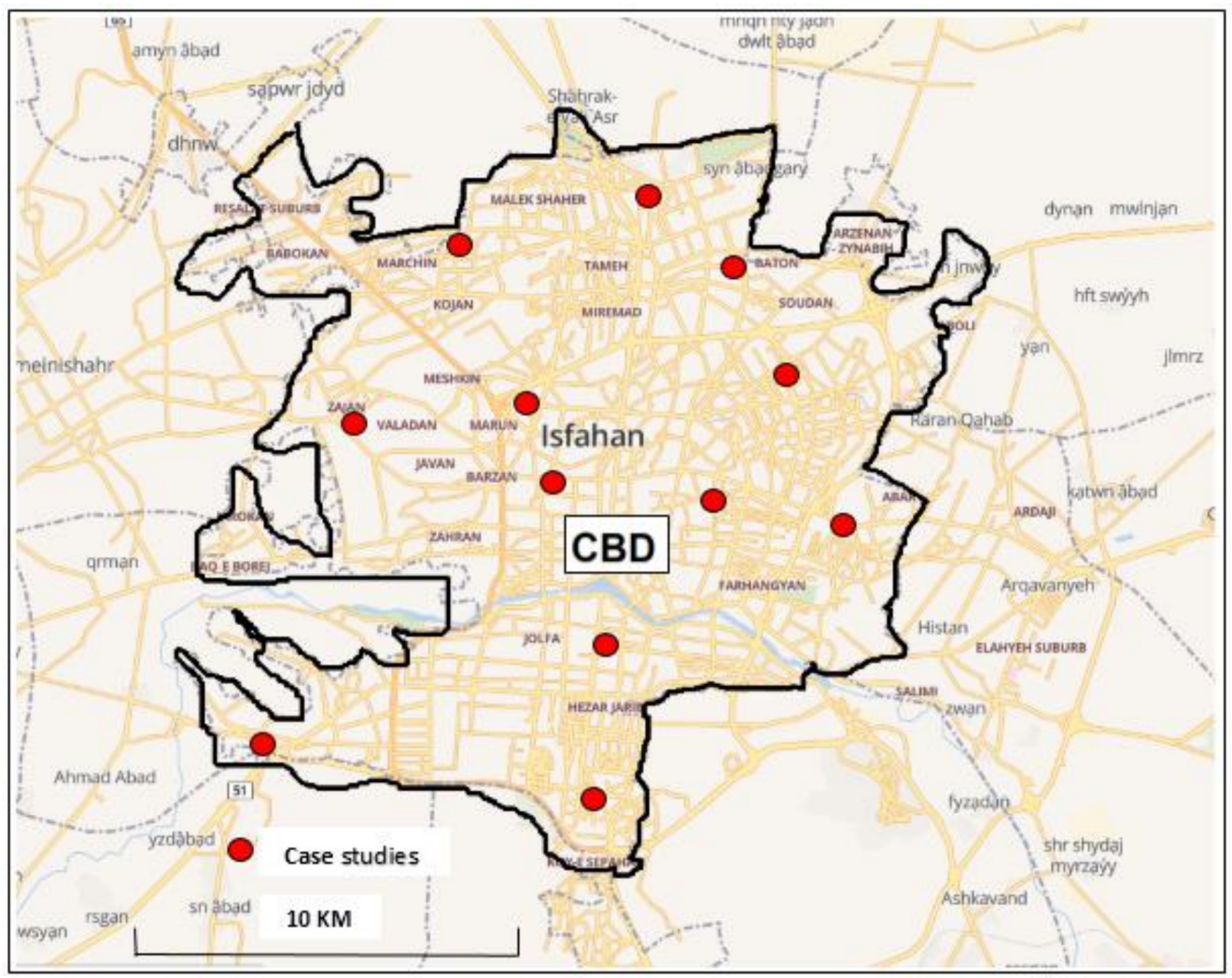

Figure 1. Location of study areas in Isfahan.

Selection of appropriate study areas was a critical step in this research. A review of the literature showed that relevant studies purposively selected a limited number of neighborhoods based on several features. For instance, Cao et al. [75] chose six neighborhoods 
from the Austin, TX area according to their development era. Cao et al. [13,76] chose eight neighborhoods according to neighborhood type, size of metropolitan area and region of the state. Pan et al. [77] chose four representative neighborhoods from the inner and outer city of Shanghai, China according to the time-periods of their development. Soltani [6] selected three neighborhoods from the inner and outer city of Shiraz, Iran according to their locations and street layout.

In the present study, we conducted a process to select appropriate neighborhoods. The process is summarized in Appendix A, which displays the cascading structure for choosing appropriate study areas. Our chief goal was to select diverse neighborhoods in terms of built environment dimensions including design, density and diversity. We potentially included all 219 neighborhoods in an initial database to capture the maximum diversity of neighborhood urban forms. In the first stage, the neighborhoods were categorized into four types (ABCD neighborhood typology) using the urban form proposals of Isfahan's detailed plan (2012) and Google Earth aerial views. The ABCD-Typology's examples and characteristics are shown in Appendix A. In brief, A-type refers to traditional and irregular urban fabric, B-type refers to semitraditional urban fabric, C-type refers to middle suburbs and relatively regular urban fabric and D-type refers to outer suburbs with a grid pattern of streets. In the second and third stages, density and land use diversity value were measured and divided into three levels: high, medium and low. Then, the neighborhoods of each urban form type were classified into three categories based on each dimension: high density and diversity, medium density and diversity and low density and diversity. As shown in Appendix B, 12 clusters were identified in total. After these processes, 219 neighborhoods were reduced to 20 neighborhoods. Finally, we picked one sample from each of the twelve clusters, which included a total of 12 neighborhoods. The process provided enough variation between case studies and allowed us to much better scrutinize the impact of the built environment features on travel behaviors.

After selecting appropriate neighborhoods, we calculated the sample size using Israel's [78] random classified sampling method (confidence level $=0.05$; sampling error $=0.05$ ). According to this method, at least 400 participants were needed as the sample size. Based on the random classified approach, all residents of the neighborhoods were marked with a specific number, and random samples were chosen using a random number table. Then, 515 questionnaires were distributed between the samples and 415 were completely answered after face-to-face interviews. Except for ages of 25-44 (which is slightly greater than that of the population), acceptable compatibility was observed by a comparison of the characteristics between sample and population. Tables 1 and 2 show the key individuals' and households' characteristics of the participants.

\subsection{Travel Habit}

In this study, the frequency of nonwork trips was considered as travel habit. In some research the frequency of behavior was understood as an indicator of habit [79]. Habit is operationally defined by Ouellette and Wood [80] as past behavior (e.g., behavior from the past week up to a year ago). Participants were requested to report the number of their nonwork trips during a normal week by three transport modes including walking/cycling, private automobile and public transportation.

\subsection{Primary Motivation of Trips and Mode Choice}

As stated, individuals may make their trips for different utilities including extrinsic, intrinsic or both. Respondents were asked to choose their last nonwork trip (during the interview day or the day before) and then report the mode choice. To measure individuals' motivations for this last nonwork trip, the teleportation test and two other statements were used as follow: "If it was possible, I would like to teleport myself to the desired destination in the blink of an eye"; "while I was going to reach a specific destination, I also wanted to change the mood of myself or my family" and "the trip was necessary at that time and it was not possible to ignore or postpone it". In this regard, we questioned participants to specify how true the above- 
mentioned statements were for the trips on a 5-point scale from "not at all" to "entirely". By analyzing the responses, four groups of respondents (or trips) with different types of motivations were recognized (see Table 3). For the first group, travel was a pure means of accessing a specific destination. For the second group, travel was mainly pursued for its own sake. In fact, intrinsic positive utility of travel for this group was much more important than reaching a desired destination. According to their primary motivation, these groups were called utilitarian trips and hedonic trips. A third group of respondents indicated that their trips were conducted for both qualities (intrinsic and extrinsic motivation) of travel as nearly equal. For the fourth group, the motivations of trips were not clear because the individuals responded to the questions inconsistently. These groups consisted of 130, 195, 35 and 55 members respectively. In this study, the two last groups were ignored because of small sample size and unclear motivation; so we focused specifically on utilitarian and hedonic groups.

Table 1. Individual's characteristics of respondents.

\begin{tabular}{ccc}
\hline \multicolumn{2}{c}{ Individuals' Characteristics } & $\begin{array}{c}\text { Sample } \\
\text { Frequency (\%) }\end{array}$ \\
\hline Sex & Female & 49 \\
\hline \multirow{2}{*}{ Age } & $17-24$ & 9.7 \\
& $25-44$ & 61.1 \\
& $45-64$ & 21.9 \\
& $>65$ & 7.2 \\
\hline \multirow{2}{*}{ Employment status } & Unemployed & 3.1 \\
& Student & 11.1 \\
& Retired & 8.6 \\
& Part time employed & 10.6 \\
& Self employed & 24.2 \\
& Full time employed & 13.1 \\
& Housewife & 29.4 \\
\hline \multirow{2}{*}{ Educational Background } & Illiterate & 0.6 \\
& Elementary & 14.7 \\
& High school & 35.6 \\
& Bachelor & 41.4 \\
& Master or Ph.D. & 7.8 \\
\hline Driving License & Yes & 76.7 \\
\hline
\end{tabular}

Table 2. Household characteristics of respondents.

\begin{tabular}{ccc}
\hline \multirow{2}{*}{ Household Characteristics } & \multicolumn{2}{c}{ Sample } \\
\cline { 2 - 3 } & Average (Std. Dev.) & Frequency (\%) \\
\hline Family Member & 3.71 & - \\
Number of employees in household & 1.55 & - \\
Number of students in household & 0.59 & - \\
People above 70 in household & 0.14 & - \\
Number of motorcycles in household & 0.37 & - \\
Number of private autos in household & 1.12 & 68.6 \\
\hline House ownership & Ownership & 48.1 \\
\hline Type of house & Apartment & 52 \\
\hline Car parking in house & Other & 90.6 \\
\hline & Yes & 34.7 \\
Household income & IRR $<20$ million & 46.4 \\
& IRR 20-35 million & 13.9 \\
\hline
\end{tabular}


Table 3. Travel characteristics of sample.

\begin{tabular}{cccccc}
\hline & \multicolumn{5}{c}{ Frequency (\%) by Modes } \\
\hline Types of Trips & Auto & Transit & Walking/Cycling & Other & Total \\
\hline Utilitarian trips & $16.1 \%$ & $3.6 \%$ & $8.9 \%$ & $1.9 \%$ & $130(31.3 \%)$ \\
Hedonic trips & $21.9 \%$ & $3.1 \%$ & $25.6 \%$ & $3.6 \%$ & $195(47 \%)$ \\
Other trips & $7.2 \%$ & $1.9 \%$ & $5.6 \%$ & 0.6 & $90(21.7 \%)$ \\
\hline Total & 188 & 36 & 166 & 25 & \multirow{2}{*}{$415(100 \%)$} \\
& $45.3 \%$ & $8.6 \%$ & $40 \%$ & $6.1 \%$ & \\
\hline No. of trips per week & 4.24 & 2.19 & 4.54 & \\
(Mean Std. dev.) & $(3.34)$ & $(2.94)$ & $(3.59)$ &
\end{tabular}

\subsection{Objective Built Environment}

Using ArcGIS 10.2 software, we measured the basic spatial characteristics of the study areas based on the updated Isfahan's detailed plan [81]. A variety of spatial variables were considered as built environment attributes. Density, design, diversity and local accessibility to transit are the most important built environment variables in the literature. We calculated these dimensions at trip origins to understand the impact of built environment on mode choice for home-based trips.

Density of population is represented by the number of inhabitants per unit area (e.g., hectare). Diversity of the built environment is measured by the Herfindahl-Hirschman Index (HHI), as an indicator of land use diversity and is calculated by the sum of squares of the percentages of each type of land us" in a unit area. In the present study, we measured residential, commercial, recreational, cultural and religious, educational, sport/medical, and vacant use as major types of land use. If a unit area is covered by one kind of land use, this index shows the maximum value of 10,000 [82]. Share of road, empty land and open and green space were calculated by dividing the area of each land use by neighborhood area and multiplying by 100 . The number of bus stations and bus lanes near the neighborhoods were measured as indicators of transit accessibility for calculating ordinal distance to the center of the Isfahan metropolitan area, which was divided into four distinctive regions from inner region to outer region. In terms of neighborhood types, we categorized four neighborhood types into two general urban forms (irregular and regular). The irregular urban form is described by nongeometric structures, curvilinear and narrow street patterns, high number of cul-de-sacs, and large residential block sizes. The regular urban form has a regular and grid street pattern, low number of cul-de-sacs and small block sizes. Table 4 displays the built environment dimensions of 12 surveyed neighborhoods.

Table 4. Summary of built environment characteristics in 12 case studies.

\begin{tabular}{ccccc}
\hline Built Environment Variable & Average & Std. Dev. & Min. & Max. \\
\hline Neighborhood area (ha) & 89.3 & 33.5 & 35 & 174 \\
Population & 12,101 & 5226 & 2720 & 23,856 \\
Number of households & 3981 & 1804 & 862 & 8076 \\
Distance to CBD (km) & 6.6 & 3.1 & 1.4 & 12 \\
Share of apartments (\%) & 67.8 & 16.02 & 33.9 & 87.6 \\
Population density (population/ha) & 132.5 & 28.25 & 77.6 & 172.8 \\
Land use mix (Herfindahl-Hirschmann Index) & 2021.6 & 772.3 & 864 & 3451 \\
Share of park and green space (\%) & 3.43 & 3.46 & 0.15 & 12.94 \\
Share of commercial/service area (\%) & 2.59 & 2.1 & 0.36 & 7.57 \\
Share of empty land use (\%) & 8.3 & 9.4 & 10 & 27.21 \\
Share of road (\%) & 32.49 & 4.15 & 25 & 36.94 \\
Number of bus lanes near the area & 4.75 & 3.34 & 1 & 14
\end{tabular}




\subsection{Subjective Variables and Clustering of Participants}

This section briefly explains about lifestyle, attitudes and sense of place statements, underlying constructs of these statements, and then clustering of participants. First, factor analysis was used to determine underlying constructs of lifestyle, attitudes and sense of place statements. Then, final scores of the underlying factors were used as inputs to the cluster analysis. In the case of lack of previous knowledge about participants' structure, cluster analysis is a helpful means to identify groups of participants who shared common characteristics under manifold dimensions. The K-Means algorithm is one of the most widely used clustering methods. The K-Means performs an iterative search of multiple data points to find the best combination of centroids for a specified number of clusters $\mathrm{K}$. The K-means algorithm tries to maximize intergroup variance and minimize intragroup variance to determine similar clusters. In the current paper, the clustering process was conducted to find groups using the criteria of "largest number of possible groups and largest number of cases explained" [83].

\subsubsection{Lifestyle}

To measure lifestyle dimensions, relevant travel behavior research has mostly used the behavioral patterns of activity and time use [66]. This paper measured lifestyles using the fields of leisure, consumption, health and technological activities. Our survey contained a list of eight leisure interests, three statements related to health and four statements related technological and cyber space activities. We requested participants to indicate how much they spent their leisure time for different leisure activities, and how much they did the activities related to health and technological and cyber space activities on a 5-point ordinal scale from "never" to "very much". After conducting a factor analysis, all items were reduced to four underlying factors (principal components analysis, Varimax rotation, and $51.57 \%$ variance explained, $\mathrm{KMO}=0.776)$, Modern Lifestyle, Healthy Lifestyle, Traditional Lifestyle and Hedonism Lifestyle (SL) (see Table 5).

Table 5. Pattern matrix for lifestyles.

\begin{tabular}{|c|c|c|c|c|}
\hline \multirow[b]{2}{*}{ Lifestyle Statements } & \multicolumn{4}{|c|}{ Lifestyle Factors } \\
\hline & $\begin{array}{l}\text { Modern } \\
\text { Lifestyle }\end{array}$ & $\begin{array}{l}\text { Healthy } \\
\text { Lifestyle }\end{array}$ & $\begin{array}{l}\text { Traditional } \\
\text { Lifestyle }\end{array}$ & $\begin{array}{l}\text { Hedonism } \\
\text { Lifestyle }\end{array}$ \\
\hline $\begin{array}{c}\text { Activity on social networks (Telegram, Instagram, Whatsapp, } \\
\text { Soroush, etc.) }\end{array}$ & 0.712 & -0.107 & - & 0.379 \\
\hline Going to restaurant or coffee shop & 0.710 & -0.119 & 0.331 & - \\
\hline Installation and use of functional applications on your phone & 0.703 & - & - & -0.149 \\
\hline $\begin{array}{l}\text { Professional activities on the Internet in relation to the job or } \\
\text { field of study }\end{array}$ & 0.686 & - & -0.136 & - \\
\hline Doing unnecessary activities and wasting time on internet & 0.627 & -0.169 & -0.170 & 0.389 \\
\hline Going to the cinema with family or friends & 0.594 & - & 0.364 & -0.132 \\
\hline Going to religious places and pilgrimages & -0.588 & - & -0.128 & -0.111 \\
\hline Avoiding overeating and eating low-fat and low-salt foods & -0.147 & 0.776 & - & -0.138 \\
\hline Performing periodic health examination or check-up & 0.147 & 0.659 & 0.147 & - \\
\hline Exercise or physical activity on a regular basis & -0.117 & 0.646 & -0.126 & 0.312 \\
\hline Going to the park and leisure place with family or friends & - & -0.151 & 0.662 & 0.341 \\
\hline Visiting family & 0.283 & 0.101 & 0.563 & -0.238 \\
\hline Presence in urban spaces & 0.302 & - & 0.534 & - \\
\hline Go to shopping malls & - & - & 0.374 & - \\
\hline Strolling on the streets without a specific destination in mind & - & - & - & 0.826 \\
\hline
\end{tabular}

In the second step, we used the final scores of the factors as inputs to the K-means clustering in order to identify clusters of similar lifestyles. Using the K-mean, participants were clustered into three homogenous groups in terms of lifestyle (see Table 6 and Figure 2). The analysis of the clusters showed that all groups were significantly different according 
to Modern Lifestyle ( $\mathrm{F}=156.530, p<0.0001)$, Healthy Lifestyle $(\mathrm{F}=212.153, p<0.0001)$, Traditional Lifestyle $(\mathrm{F}=30.36, p<0.0001)$, and Hedonism Lifestyle $(\mathrm{F}=52.6, p<0.0001)$.

Table 6. Homogenous clusters of lifestyles.

\begin{tabular}{|c|c|c|c|}
\hline & \multicolumn{3}{|c|}{ Cluster } \\
\hline & Cluster 1 & Cluster 2 & Cluster 3 \\
\hline Lifestyle Factors & $\begin{array}{l}\text { Traditional, Healthy } \\
\text { \& Hedonism }\end{array}$ & $\begin{array}{l}\text { Semi-Modern, } \\
\text { Semihedonism \& } \\
\text { Unhealthy }\end{array}$ & $\begin{array}{l}\text { Modern, Healthy \& } \\
\text { Unhedonism }\end{array}$ \\
\hline Modern Lifestyle & -0.76387 & -0.02793 & 0.93059 \\
\hline Healthy Lifestyle & 0.569 & -1.0059 & 0.61274 \\
\hline Traditional Lifestyle & 0.62136 & -0.10156 & -0.3372 \\
\hline Hedonism Lifestyle & 0.45883 & -0.08067 & -0.3147 \\
\hline Total member (\%) & 35.3 & 34.7 & 30 \\
\hline
\end{tabular}

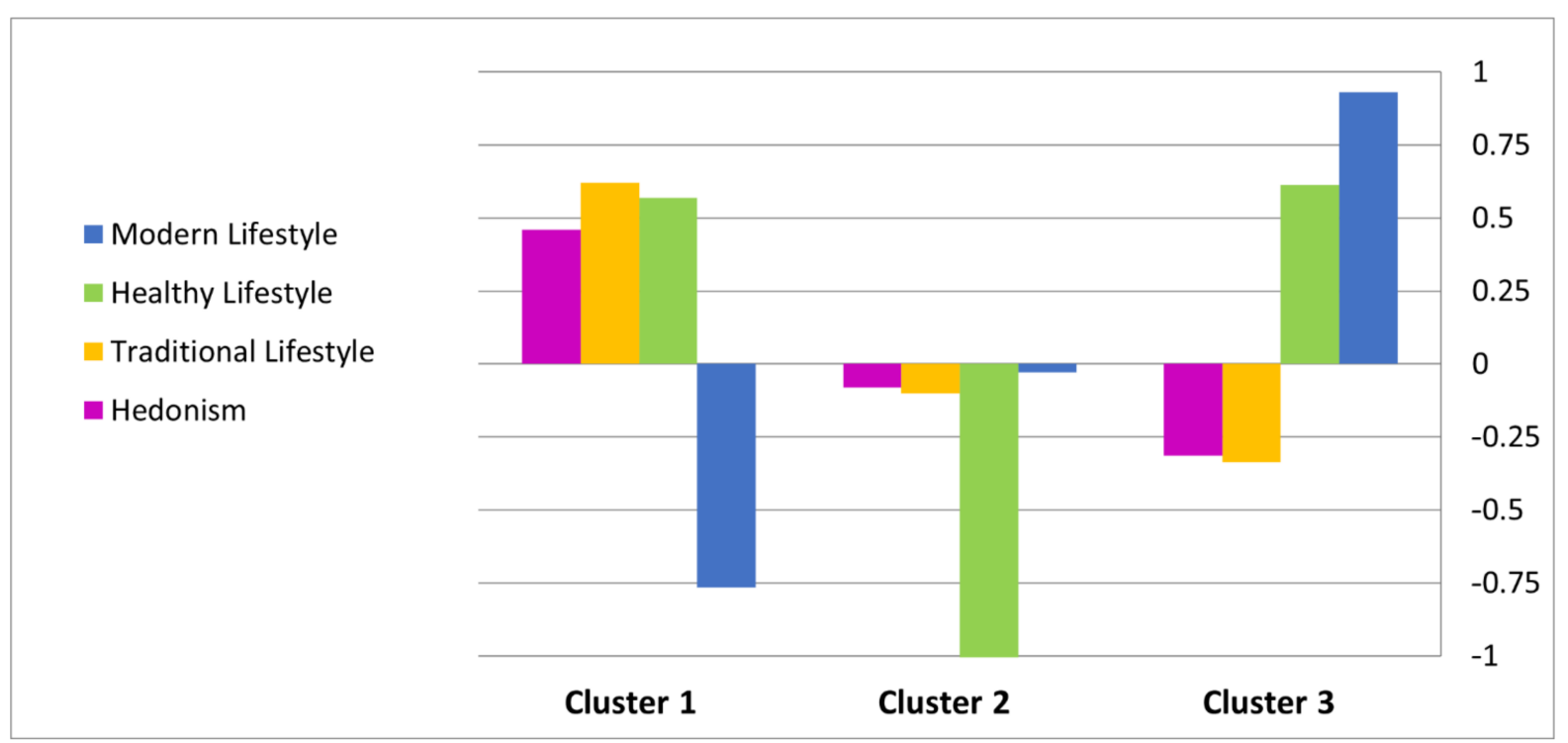

Figure 2. Homogenous clusters of lifestyles.

Cluster 1 had a Traditional, Healthy and Hedonism lifestyle. Cluster 2 was characterized by Semimodern, Semihedonism \& Unhealthy lifestyle. Cluster 3 had a Modern, Healthy and Unhedonism lifestyle.

\subsubsection{Attitudes}

Recent research has analyzed the contribution of travel attitudes in explaining travel behavior by exploring people's travel likes and dislikes, their opinions about environmental issues, their views about commute benefits, and their sense about travel freedom and travel stress [11,84]. This paper concentrates on individuals' attitudes toward several traffic management policies. Participants were questioned to state how much they agreed or disagreed with five statements on a 5-point Likert scale from "strongly disagree" to "strongly agree". By conducting factor analysis (principal components analysis, Varimax rotation, and $71.5 \%$ variance explained, $\mathrm{KMO}=58.3$ ), these five items were extracted into three factors: Pro-Physical development, Pro-transit \& car limitation, Pro-increasing fuel price (see Table 7). 
Table 7. Pattern matrix for attitudes.

\begin{tabular}{|c|c|c|c|}
\hline \multirow[b]{2}{*}{ Attitude Statements } & \multicolumn{3}{|c|}{ Attitude Factors } \\
\hline & $\begin{array}{l}\text { Pro-Physical } \\
\text { Development }\end{array}$ & $\begin{array}{l}\text { Pro-Transit \& Car } \\
\text { Limitation }\end{array}$ & $\begin{array}{c}\text { Pro-Increasing } \\
\text { Fuel Price }\end{array}$ \\
\hline $\begin{array}{l}\text { To solve the traffic problem in the city of Isfahan we need to } \\
\text { create more parking. }\end{array}$ & 0.830 & -0.143 & -0.145 \\
\hline $\begin{array}{l}\text { To solve the traffic problem in the city of Isfahan we need to } \\
\text { create more streets and wide many streets. }\end{array}$ & 0.765 & 0.158 & 0.205 \\
\hline $\begin{array}{l}\text { To solve the traffic problem and air pollution in the city of } \\
\text { Isfahan transit infrastructures should be developed. }\end{array}$ & - & 0.858 & -0.198 \\
\hline I agree with the traffic plans which limit using private cars. & 0.123 & 0.618 & 0.428 \\
\hline $\begin{array}{l}\text { I really agree with the increase in the price of fuel (gasoline and } \\
\text { petrol) to control the pollution and traffic in the city of Esfahan. }\end{array}$ & - & - & 0.912 \\
\hline
\end{tabular}

Similar to lifestyle, participants were clustered into three homogenous groups in terms of attitudes using K-mean cluster (see Table 8 and Figure 3). The analysis of the clusters showed that all groups were significantly different according to Pro-Physical development $(\mathrm{F}=133.914, p<0.0001)$, Pro-transit \& car limitation $(\mathrm{F}=42.845, p<0.0001)$ and Pro-increasing fuel price $(\mathrm{F}=311.507, p<0.0001)$. Respondents belonging to cluster 1 were mainly pro-increasing fuel price. Cluster 2 was characterized by pro-transit and car limitation. Individuals of cluster 3 were also described by pro-physical development.

Table 8. Homogenous clusters of attitudes.

\begin{tabular}{cccc}
\hline \multirow{2}{*}{ Attitude Factors } & \multicolumn{3}{c}{ Cluster } \\
\cline { 2 - 4 } & Cluster 1 & Cluster 2 & Cluster 3 \\
\cline { 2 - 4 } & $\begin{array}{c}\text { Pro-Increasing } \\
\text { Fuel Price }\end{array}$ & $\begin{array}{c}\text { Pro-Transit \& } \\
\text { Car Limitation }\end{array}$ & $\begin{array}{c}\text { Pro-Physical } \\
\text { Development }\end{array}$ \\
\hline Pro-Physical development & 0.22668 & -1.03987 & 0.95043 \\
Pro-transit \& car limitation & -0.12678 & 0.79146 & -0.27137 \\
Pro-increasing fuel price & 1.91535 & -0.13644 & -0.41458 \\
\hline Total member $(\%)$ & 14.4 & 28.1 & 57.5 \\
\hline
\end{tabular}

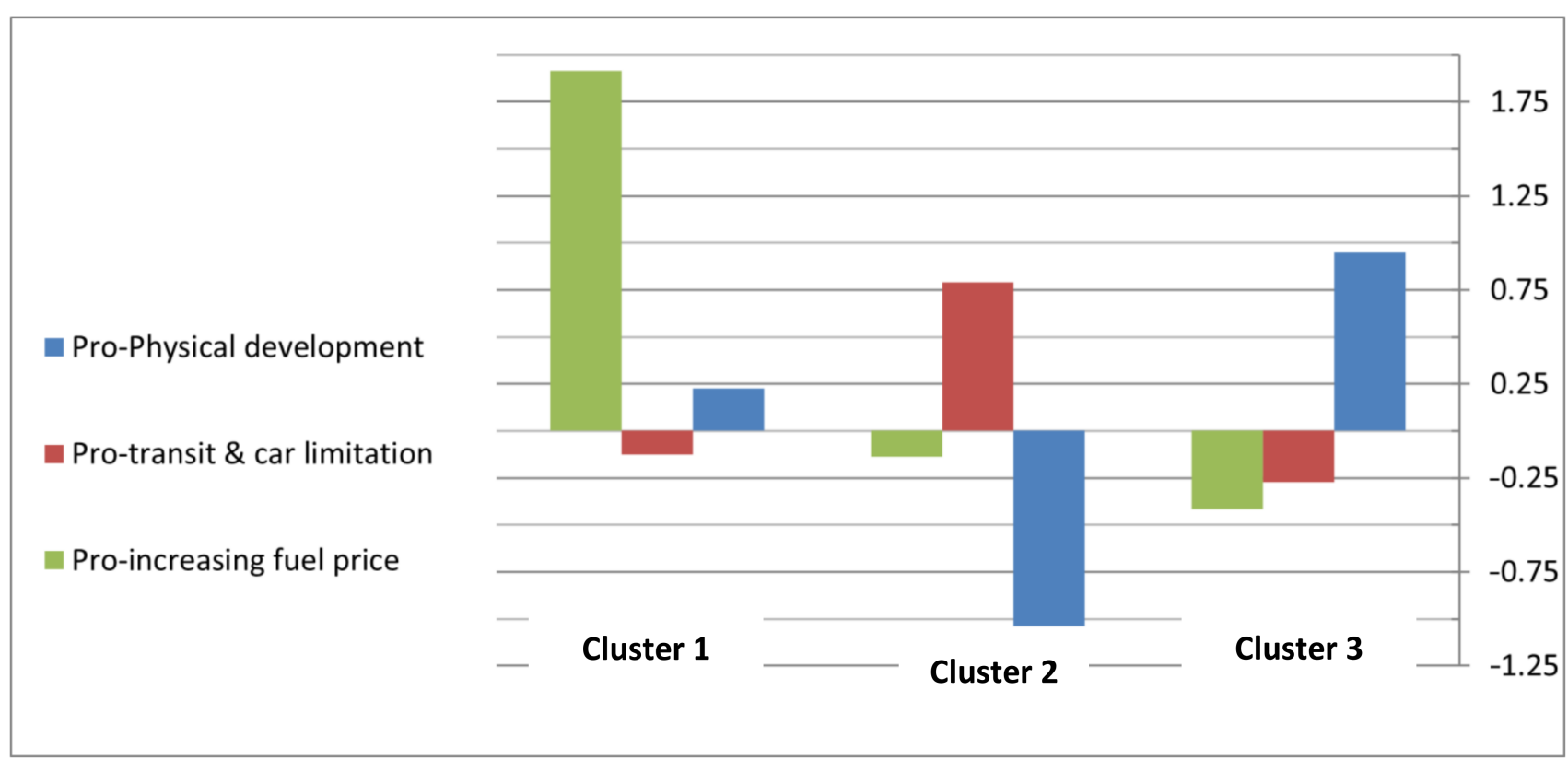

Figure 3. Homogenous clusters of attitudes. 


\subsubsection{Sense of Place}

Despite attitudes toward travel behavior and different transport modes, attitudes toward places or attributes of human-place interaction have received less attention. In travel behavior modelling it is important to consider the emotional and affective interactions with place besides physical and need-based interaction with environment [85].

Following the literature on travel behavior and sense of place $[85,86]$, we adapted a series of statements relating the respondents' sense of place. Similar to previous subjective variables, participants were questioned to state how much they agreed or disagreed with nine statements on a 5-point Likert scale from "strongly disagree" to "strongly agree". By conducting factor analysis (principal components analysis, Varimax rotation, 57\% variance explained, $\mathrm{KMO}=0.676$ ), these statements were extracted into three factors: place satisfaction, place attachment and community, and place safety and beauty (see Table 9).

Table 9. Pattern matrix for sense of place.

\begin{tabular}{ccc}
\hline Sense of Place Statements & Sense of Place Factors \\
\cline { 2 - 3 } & Satisfaction & $\begin{array}{c}\text { Attachment \& } \\
\text { Community-Oriented }\end{array}$ \\
\hline Shere are various shops within walking distance. & 0.823 & 0.146 \\
$\quad$ I go out of the neighborhood less to meet my needs. & 0.750 & 0.124 \\
Access to public transport is satisfactory in this neighborhood. & 0.728 & 0.766 \\
I have warm relations with neighbors in the neighborhood. & & 0.727 \\
$\quad$ I have a lot of memories with this neighborhood. & 0.232 & 0.504 \\
I do not like to migrate from this neighborhood to another. & 0.196 & 0.146 \\
$\quad$ Our neighborhood is a safe neighborhood. & 0.177 & 0.166 \\
Traffic and bustle in our neighborhood are annoying. & 0.304 & -0.198 \\
The facade of the buildings and the landscape of our & 0.495 & 0.448 \\
neighborhood are beautiful and attractive. & & 0.676 \\
\hline
\end{tabular}

In the next step, the cluster analysis categorized participants into two homogenous groups in terms of sense of place (see Table 10 and Figure 4). The ANOVA analysis of the clusters showed that all clusters were significantly different according to Place satisfaction $(\mathrm{F}=607.709, p<0.0001)$, Place attachment and Community $(\mathrm{F}=81.364, p<0.0001)$, Place safety and beauty $(\mathrm{F}=193.453, p<0.0001)$. Cluster 1 's respondents mainly had a strong sense of place according to all three factors, whereas respondents belong to cluster 2 had a weak sense of place.

Table 10. Homogenous clusters of sense of place.

\begin{tabular}{ccc}
\hline Sense of Place Factor & $\begin{array}{c}\text { Cluster 1 } \\
\text { Strong Sense of Place }\end{array}$ & $\begin{array}{c}\text { Cluster 2 } \\
\text { Weak Sense of Place }\end{array}$ \\
\hline Satisfaction & 0.64962 & -0.7344 \\
Attachment and Community-oriented & 0.32364 & -0.28398 \\
Safety and Beauty & 0.53303 & -0.43575 \\
\hline Total member $(\%)$ & 45.6 & 54.4 \\
\hline
\end{tabular}

\subsection{Analysis Method}

We developed a series of binary logistic models to analyze the associations between the built environment variables and travel mode choice for utilitarian and hedonic trips, controlling for subjective variables and socio-demographic characteristics. 
Logistic regression is commonly used when the dependent variable is a dichotomous variable (for example, car use $=1$ and no car use $=0$ ). The general formula of a binary logistic model is:

$$
\text { Logit } \mathrm{P}=\ln \frac{p}{1-p}=\alpha+\sum_{i=1}^{k} \beta i x i
$$

where $\mathrm{P}=$ the probability of $\mathrm{Y}=1 ; x_{i}=$ each independent variable; $\alpha=$ constant value; $\beta i=$ regression coefficient.

$$
\mathrm{P}=\frac{\exp \left(\alpha+\sum_{i=1}^{k} \beta i x i\right)}{1+\exp \left(\sum_{i=1}^{k} \beta i x i\right)}
$$

Several parameters including Log likelihood (sometimes replaced by -2log likelihood), Cox and Snell $R^{2}$, Nagelkerke $R^{2}$ (as a modification of Cox and Snell $R^{2}$ ) have been proposed to assess the fitness of logistic models. A larger value of these parameters indicates that the model is more accurate. Cox and Snell $R^{2}$ (like $R^{2}$ in linear regression model) describes the portion of the variation in the outcome which is explained by the independent variables. [87].

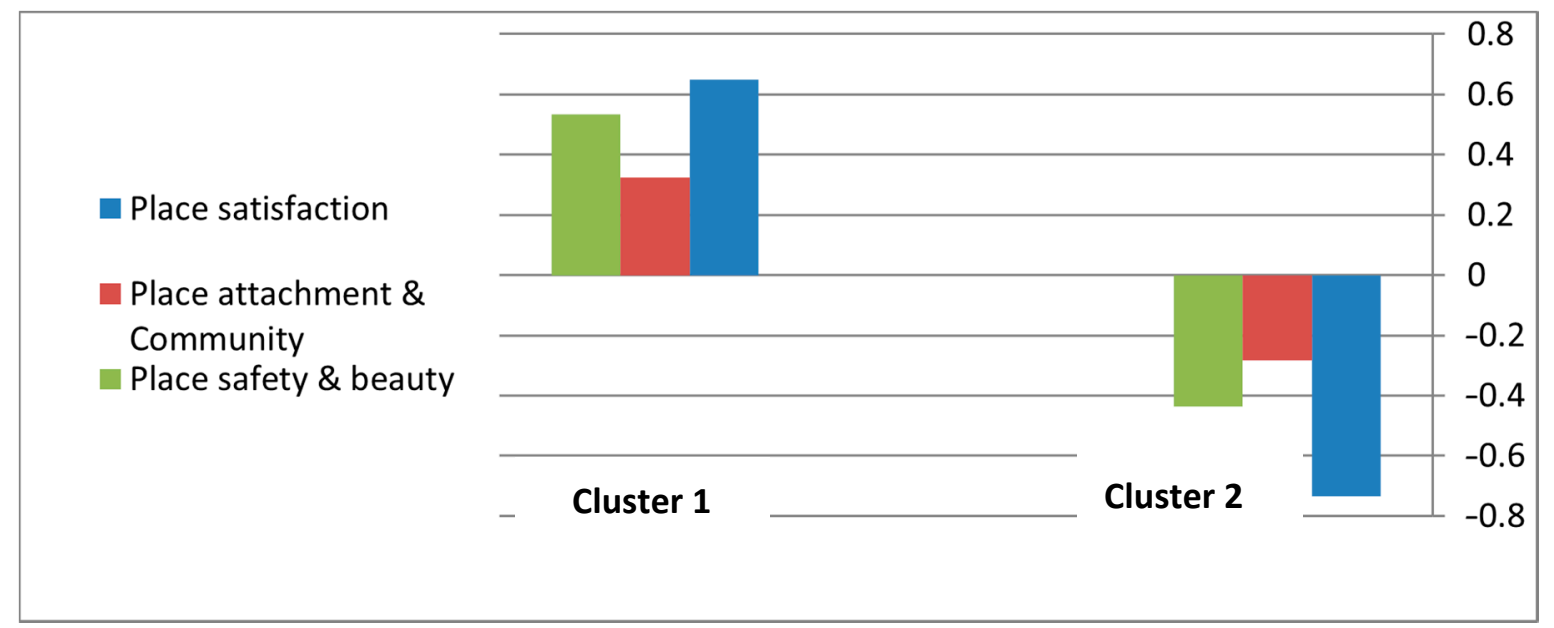

Figure 4. Homogenous clusters of sense of place.

\section{Results and Discussion}

\subsection{Walking/Cycling Behaviour}

Two binary logistic models were developed to investigate the influence of the objective built environment on walking/cycling for hedonic and utilitarian trips, controlling for subjective variables including lifestyle, travel attitudes, sense of place and socio-demographic characteristics. All pseudo- $R^{2}$ parameters demonstrated that these models fitted the data satisfactory (Table 11). Indeed, before mode choice modeling, we tested multicollinearity of variables by calculating the variance inflation factor (VIF) and tolerance values (1/VIF). The results of the parameters showed that there was no multicollinearity concern here (VIF was less than 10 and tolerance was more than 0.10 for all variables) [88].

Table 11. The results of the test for walking/cycling models.

\begin{tabular}{ccc}
\hline \multicolumn{2}{c}{ Hedonic Walking/Cycling } & Utilitarian Walking/Cycling \\
\hline Summary Statistics & Value & Value \\
\hline Chi-square (df) & 87.26 & 57.196 \\
-2 Log likelihood & 182.450 & 75.45 \\
Cox \& Snell $R$ Square & 0.361 & 0.405 \\
Nagelkerke $R$ Square & 0.482 & 0.58 \\
\hline
\end{tabular}


Results of the logistic regression for walking/cycling behavior for hedonic and utilitarian trips are summarized in Table 12 . The present results clearly confirmed that walking/cycling is not a single behavior and each type of walking is influenced by a different set of variables. Explanatory variables including socio-economics, sense of place, travel habit and built environment characteristics, appeared differently in both models in terms of significance and importance. Among the socio-economic factors, sex, family size and income were significant in the hedonic walking/cycling model, and sex, age and job had an impact on utilitarian walking/cycling. Men found lower utility to choose walking/cycling for both types of walking/cycling compared to women. This finding further confirmed the role of gender differences, which was reflected in earlier studies [55,57]. Family size had a positive association with hedonic walking/cycling. This result is inconsistent with previous studies which claimed that household size is positively associated with car ownership and car use [41]. People at income level 2 were less likely to make hedonic walking/cycling compared to the reference group (people at lowest income level). People of 25-64 years old had a tendency to make walking/cycling for utilitarian trips compared to those who were younger. In general, these findings are supported by previous research, as mentioned in the literature section. Consistent with earlier findings [41,59], being a student had a positive association with walking/cycling. Sense of place did not significantly contribute to hedonic walking but had a significant and important impact on utilitarian walking. Having a weak sense of place negatively influenced an individual's likelihood of walking for utilitarian trips. This means that place satisfaction, place attachment and community, and place safety and beauty as underlying constructs of sense of place had a significant contribution to the likelihood of walking/cycling. Wang [89] claims that "places shape individuals' engagement in activities and trip making behavior". Deutsch and Goulias [90] concluded that having interaction with neighbors positively influenced the chance of walking to the destination. If people had an unsafe feeling when walking around the neighborhoods, they would be less likely to choose walking/cycling. Further, travel habit variables had a substantial effect on travel mode choice decision for both types of travel. A walking/cycling habit significantly increased the chance of choosing walking/cycling for both hedonic and utilitarian trips. Instead, car usage habit and transit usage habit had a negative impact on the use of utilitarian walking/cycling. These significant results are consistent with previous finding on travel habit-mode choice selection. Havličková1 and Zámečník [79] indicated that, travel habit is the strongest factor in the model for changing travel mode choice decision.

From the built environment, we found that several features differently appeared in the models for both hedonic and utilitarian walking/cycling. As the only common variable in our models, people who were living in neighborhoods of the second region were more likely to do hedonic walking/cycling and less likely to do utilitarian walking/cycling. This may be due to this fact that the consequence of high traffic congestion in the first region (CBD), such as lack of safety, discouraged individuals from hedonic walking/cycling. Residents living in mixed-land use and dense neighborhoods had a higher tendency to utilitarian walking/biking. Often, these results were supported by previous research (see [41-43,91]). Density intensification and mixed land uses reduced the distance between activities and made the built environment more attractive for walking. In line with the literature, the number of bus lane within a neighborhood was positively associated with hedonic walking. Increase in share of the road and living in irregular neighborhoods had a negative impact on the likelihood of hedonic waking/cycling. Regarding road density, previous research reported mixed results. Some studies showed that road density reduced the use of private cars and increased more sustainable modes through increasing internal connectivity [92,93]. Nonetheless, Etminani-Ghasrodashti and Ardeshiri [43] found that higher street density was associated with lower walking for nonwork trips. This may be due to the fact that increase in share of the road probably encourages motorized traffic and decreases pedestrian safety [43]. 
Table 12. The results of the binary logistic models for walking/cycling trips.

\begin{tabular}{|c|c|c|c|c|c|c|c|c|c|}
\hline \multirow[b]{2}{*}{ Variables } & \multicolumn{4}{|c|}{ Hedonic Walking } & \multicolumn{5}{|c|}{ Utilitarian Walking/Cycling } \\
\hline & B & S.E. & Wald & Sig. & B & S.E. & Wald & Sig. & Exp. (B) \\
\hline Constant & 14.65 & 6.038 & 6.887 & 0.015 & -28.172 & 13.441 & 4.393 & 0.036 & - \\
\hline \multicolumn{10}{|l|}{ Socio-economics * } \\
\hline Sex (male) & -1.010 & 0.567 & 3.171 & 0.075 & -4.653 & 1.735 & 7.188 & 0.007 & 0.01 \\
\hline Age: $25-44$ years & & & & & 0.142 & 0.06 & 5.537 & 0.019 & 1.152 \\
\hline Age: $45-64$ years & & & & & 0.14 & 0.065 & 5.54 & 0.071 & 1.153 \\
\hline Family size & 0.361 & 0.208 & 3.019 & 0.082 & & & & & \\
\hline Student & & & & & 4.437 & 2.404 & 3.405 & 0.065 & 84.494 \\
\hline Income (IRR 20-35 million) & -1.449 & 0.87 & 2.771 & 0.096 & & & & & \\
\hline \multicolumn{10}{|l|}{ Sense of place * } \\
\hline Weak sense & & & & & -2.584 & 1.153 & 5.021 & 0.025 & 0.075 \\
\hline \multicolumn{10}{|l|}{ Travel habit } \\
\hline Car use habit & & & & & -0.530 & 0.241 & 4.481 & 0.028 & 0.589 \\
\hline Transit use habit & & & & & -0.389 & 0.213 & 3.324 & 0.068 & 0.678 \\
\hline Walking/cycling habit & 0.382 & 0.083 & 21.441 & 0.000 & 0.614 & 0.209 & 8.673 & 0.003 & 1.484 \\
\hline Population density & & & & & 0.389 & 0.213 & 3.324 & 0.068 & 0.678 \\
\hline Land use mixing & & & & & 0.614 & 0.209 & 8.673 & 0.003 & 1.484 \\
\hline Share of road & -0.535 & 0.2 & 7.157 & 0.007 & & & & & \\
\hline Number of bus lanes & 0.258 & 0.146 & 3.119 & 0.077 & & & & & \\
\hline Neighborhood types (irregular) & -1.588 & 0.837 & 3.601 & 0.058 & & & & & \\
\hline Neighborhoods in the 2 nd region & 3.342 & 1.935 & 2.982 & 0.084 & -7.404 & 4.414 & 3.198 & 0.074 & 0.001 \\
\hline
\end{tabular}

*Age (Ref. = 0-24 year), Job (Ref. = Unemployed group), Income (Ref. = IRR $<20$ million), Sense of place (Ref. = strong sense of place),

Distance to CBD (Ref. = neighborhoods in the first region).

These results indicate that considering two different types of walking as a single behavior may reveal inconsistent or biased results in terms of importance, direction and significance of relationship. This suggests that type-specific policies should be prescribed to encourage walking behavior.

\subsection{Driving Behaviour}

Like walking/biking trips, two binary logistic models were developed for two types of driving. All pseudo- $R^{2}$ parameters demonstrated that these models fitted the data satisfactory (Table 13).

Table 13. The results of the test for driving models.

\begin{tabular}{ccc}
\hline \multirow{2}{*}{ Summary Statistics } & Hedonic Driving & Utilitarian Driving \\
\cline { 2 - 3 } & Value & Value \\
\hline Chi-square (df) & 104.919 & 108.157 \\
- 2 Log likelihood & 148.501 & 43.42 \\
Cox \& Snell $R$ Square & 0.416 & 0.626 \\
Nagelkerke $R$ Square & 0.572 & 0.837 \\
\hline
\end{tabular}

Like walking behavior, the results revealed that driving for hedonic and utilitarian trips also were not a single behavior. Comparison of both models showed that explanatory variables appeared differently in the model for both types of driving (Table 14). While hedonic driving was influenced by socio-economics, lifestyle and travel habit, utilitarian driving was influenced by more explanatory factors including socio-demographics, attitudes, travel habit, sense of place and built environment. 
Table 14. The results of the binary logistic models for driving trips.

\begin{tabular}{|c|c|c|c|c|c|c|c|c|c|c|}
\hline \multirow[b]{2}{*}{ Variables } & \multicolumn{5}{|c|}{ Hedonic Walking } & \multicolumn{5}{|c|}{ Utilitarian Walking/Cycling } \\
\hline & B & S.E. & Wald & Sig. & Exp. (B) & B & S.E. & Wald & Sig. & Exp. (B) \\
\hline Constant & -14.907 & 6.486 & 5.283 & 0.022 & - & 17.57 & 15.1 & 1.35 & 0.245 & - \\
\hline \multicolumn{11}{|l|}{ Socio-economics * } \\
\hline Sex (male) & 1.575 & 0768 & 4.204 & 0.04 & 4.83 & 2.966 & 1.54 & 3.7 & 0.054 & 19.41 \\
\hline Age: $25-44$ years & 5.247 & 1.791 & 8.578 & 0.003 & 189.98 & & & & & \\
\hline Age: $45-64$ years & 5.225 & 1.868 & 7.825 & 0.005 & 185.83 & & & & & \\
\hline Student & 4.291 & 2.089 & 4.22 & 0.04 & 73.068 & -4.319 & 2.242 & 3.713 & 0.054 & 0.013 \\
\hline Family size & -0.715 & 0.277 & 6.652 & 0.01 & 0.489 & & & & & \\
\hline Income: IRR 20-35 million & 2.414 & 0.944 & 6.539 & 0.011 & 11.173 & & & & & \\
\hline Income: IRR > 50 million) & 4.439 & 1.813 & 5.996 & 0.014 & 84677 & & & & & \\
\hline \multicolumn{11}{|l|}{ Attitudes * } \\
\hline Pro-transit and car limitation & & & & & & 4.777 & 1.999 & 5.707 & 0.017 & 118.70 \\
\hline Pro-physical development & & & & & & 4.645 & 1.808 & 6.598 & 0.01 & 104.19 \\
\hline \multicolumn{11}{|l|}{ Lifestyle * } \\
\hline $\begin{array}{l}\text { Semi-modern/hedonism } \\
\text { and unhealthy }\end{array}$ & 1.234 & 0.7 & 3.105 & 0.078 & 3.434 & & & & & \\
\hline \multicolumn{11}{|l|}{ Sense of place } \\
\hline Weak sense & & & & & & 2.058 & 1.132 & 3.303 & 0.069 & 7.831 \\
\hline \multicolumn{11}{|l|}{ Travel habit } \\
\hline Car use habit & 0.397 & 0.11 & 12.908 & 0.000 & 1.487 & 0.557 & 0.193 & 8.356 & 0.004 & 1.745 \\
\hline Transit use habit & -0.247 & 0.121 & 4.155 & 0.042 & 0.781 & -0.413 & 0.236 & 3.08 & 0.079 & 0.661 \\
\hline Walking/cycling habit & -0.386 & 0.091 & 17.845 & 0.000 & 0.68 & -0.661 & 0.253 & 6.828 & 0.009 & 0.516 \\
\hline \multicolumn{11}{|l|}{$\begin{array}{l}\text { Objective built } \\
\text { environment }\end{array}$} \\
\hline Population density & & & & & & -0.053 & 0.028 & 3.656 & 0.056 & 0.948 \\
\hline Land use mixing & & & & & & -0.003 & 0.002 & 4.241 & 0.039 & 0.997 \\
\hline
\end{tabular}

* Age (Ref. = 0-24 year), Job (Ref. = Unemployed group), Income (Ref. = IRR $<20$ million), Attitudes (Ref. = pro-increasing fuel cost),

Lifestyle (Ref. $=$ Traditional, healthy and hedonism lifestyle), Sense of place (Ref. = strong sense of place).

Among socio-economic variables, it was found that individuals who are male and older than 25 years found higher utility in using a car for hedonic trips. These may be attributed to car availability for these groups, and convenience and security issues of this mode. Our results relating to age and gender are generally consistent with some previous research (e.g., $[37,39,77])$. In addition, being a student, car ownership and being at the highest level of income positively contributed to the overall likelihood of a person taking part in hedonic driving. As mentioned previously, these results echoed past findings. Increase in family size decreased the likelihood of hedonic driving. This result does not support the argument of previous studies that car use is higher within large households [54]. For utilitarian trips, only two socio-economic characteristics, including sex (being male) and job (being a student), had a positive and negative association with driving, respectively. It seems that students have "symbolic" and/or "affective motives" for car use, especially for hedonic trips (see [94]). Clusters of respondents based on attitudes did not significantly appear in the model for hedonic driving, but they were significantly present for utilitarian driving. Compared to the reference group, people who were in favor of public transportation and car limitation plans, and who were in favor of physical development, were more likely to drive for utilitarian trips. These results are reasonable because those who were in favor of increasing fuel price usually had a stricter attitude toward car usage. Consistent with some previous studies [13,70], these results developed the role of some other attitudes in explaining travel mode choice. Individuals' sense of place did not significantly contribute to hedonic driving but having a weak sense of place increased the likelihood of car use for utilitarian trips. Contrary to sense of place, lifestyle did not matter for utilitarian driving, but it significantly contributed to the model for hedonic driving. Compared to the reference cluster (those who had a traditional, hedonism and healthy lifestyle), people who 
had a semi-traditional/modern and unhealthy lifestyle were more likely to use a car for hedonic trips. Further, travel habits significantly contributed to both models of hedonic and utilitarian driving. A car usage habit positively contributed to the overall probability to use a car for both hedonic and utilitarian driving. In contrast, car usage habit and transit usage habit were negatively associated with car use for both hedonic and utilitarian driving. As Triandis $[95,96]$ indicated, these findings support the idea that mode choice decision is generally a consequence of "habit and intention". Thus, it is necessary to consider travel habit in mode choice modeling to improve estimation power. In this context, policy makers should work with habit if they want to encourage more sustainable transport modes [79].

Finally, we found that driving for hedonic trips was not influenced by built environment measurements. Thus, this result does not exactly confirm with previous findings on the significant relationship between the built environment and travel behavior. Instead, probability of driving for utilitarian trips decreased with increasing population density and mixed land use. The results relating to utilitarian driving are supported by a considerable number of previous studies $[33,35,39]$.

\section{Conclusions}

The contribution of this study was to introduce a practical approach for distinguishing between utilitarian trips and hedonic trips based on their primary motivation, as well as incorporating such motivations in travel mode choice modeling in the context of a developing country, Iran. In this regard, four binary regression models were separately developed to investigate how built environment measurements affect car use and walking/cycling decisions, controlling for socio-economics, lifestyle, travel habit and subjective attitudes toward travel management and sense of place.

The results revealed some interesting insights. First, surprisingly, the share of hedonic trips was sizably greater than utilitarian trips. Second, the results clearly showed that walking/cycling and driving behavior was not a single behavior, and explanatory variables appeared differently in four models for walking/cycling and driving in terms of significance, importance and direction. Thus, the consideration of the different types of walking or driving as a single behavior may reveal inconsistent and biased results. It suggests that policy makers should prescribe specific policies to improve walking/biking. Third, travel habit, especially the walking/cycling habit, had a substantial influence on hedonic and utilitarian trips by both modes. The findings suggest that if people did not change their travel habits, it might be difficult to impact on driving behavior using built environment-transportation strategies, especially for persons who forecast utility from hedonic driving. Fourth, we surprisingly found that spatial characteristics did not influence hedonic driving when controlling for other related factors. For other models, some built environment characteristics, including population density, mixed land use, share of road, number of bus lane and neighborhood types were significantly associated with travel modes. Finally, we found that some individual variables (being male and student, weak sense of place, driving and walking habit) along with land use mix and population density significantly impacted on utilitarian walking/cycling and driving in opposite directions. The simultaneous opposing impact of variables strengthens the assumption of transport mode substitution [13]. These results suggest that increasing density and providing mixed activities may lead to walking/cycling instead of driving for utilitarian trips. For hedonic trips, being male, family size and walking/cycling habit influenced both modes in opposing ways. It is worth noting that comparing our results to the literature shows that most of the results are generally in line with previous findings. However, there are several mismatches that should be considered in developing countries. For example, the positive (negative) association of family size with walking (driving) is inconsistent with previous studies. We found share of road was negatively related to hedonic walking. This result is consistent with from Etminani-Ghasrodashti and Ardeshiri [43] in Iran, and Zhao [38] from China, but inconsistent with most research from developed countries [92,93]. Furthermore, this study did not reveal a significant relationship between hedonic car use 
and the built environment. In particular, Cao, Mokhtarian and Handy [13] found that the built environment significantly impacted on undirected driving.

As for the limitations of this study, it is noted that the current variable set was insightful for understanding the relationship between the built environment and mode choice. However, these results may change under additional different built environment variables or other statements related to travel attitude, lifestyle and sense of place. Moreover, we identified only two types of travel in this paper, while standard travel surveys could be improved to obtain travel motivations more fully, and to identify trips that may have some of both travel qualities.

Author Contributions: Conceptualization, E.M. and D.M.; methodology, E.M. and D.M.; validation, E.M. and D.M.; formal analysis, E.M. and D.M.; investigation, E.M.; resources, E.M.; data curation, E.M.; writing—original draft preparation, E.M. and D.M.; writing—review and editing, E.M. and D.M.; visualization, E.M.; supervision, D.M.; project administration, E.M. and D.M. All authors have read and agreed to the published version of the manuscript.

Funding: The research received no external funding.

Institutional Review Board Statement: Because of the nature of the research and authors, we were not required to have formal approval of the institutional review board of the local ethics. However all subjects gave their informed consent for inclusion before they participated in the study. The study was conducted in accordance with the Declaration of Helsinki.

Informed Consent Statement: Informed consent was obtained from all subjects involved in the study.

Data Availability Statement: The data presented in this study are available on request from the corresponding author. The data are not publicly available due to privacy.

Conflicts of Interest: The authors declare no conflict of interest. 


\section{Appendix A. The Process of Sample Selection}

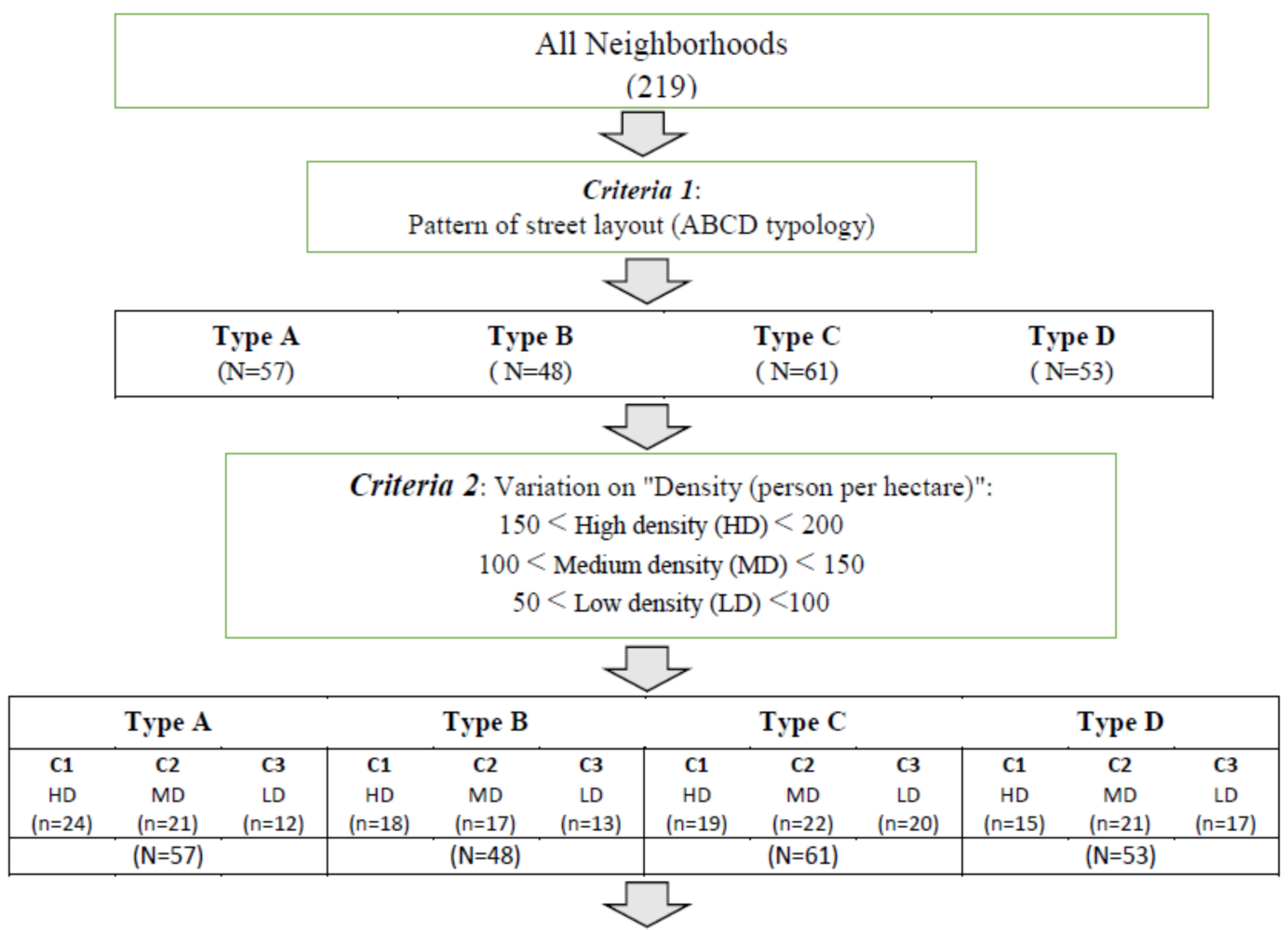

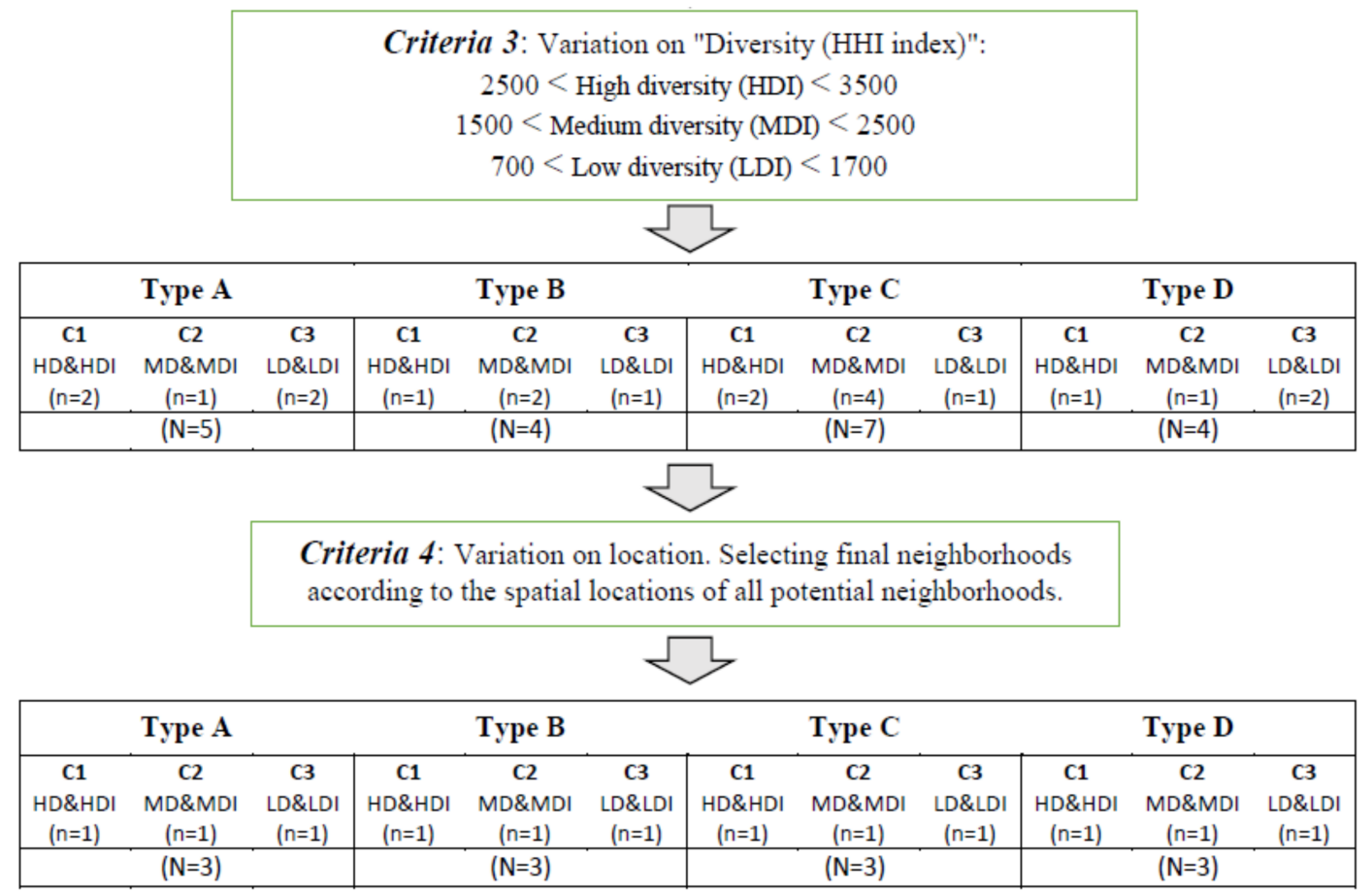

Figure A1. The process of sample selection option. 


\section{Appendix B. ABCD-neighborhood Typology in Isfahan}

Table A1. ABCD-neighborhood typology in Isfahan.

\begin{tabular}{|c|c|c|}
\hline Type & Example Pattern & Characteristics \\
\hline A-type & & $\begin{array}{ll}\text { - } & \text { Traditional urban fabric } \\
\text { - } & \text { Organic street network } \\
\text { - } & \text { High cul-de-sac density } \\
\text { - } & \text { Narrow street } \\
\text { - } & \text { Curved street } \\
\text { - } & \text { Nongeometric and large block }\end{array}$ \\
\hline B-type & & $\begin{array}{ll}- & \text { Semi-traditional urban fabric } \\
- & \text { Mixed patterns of street network } \\
\text { (organic and grid) } \\
- & \text { Relatively high cul-de-sac density } \\
- & \text { Relatively narrow streets } \\
- & \text { Curved streets } \\
- & \text { Relatively nongeometric block }\end{array}$ \\
\hline C-type & & $\begin{array}{ll}\text { - } & \begin{array}{l}\text { Developed within the last } 40 \text { years } \\
\text { (middle suburb) }\end{array} \\
\text { - } & \text { Regular and grid pattern of streets } \\
- & \text { Geometric block size } \\
- & \text { Wide and standard street } \\
- & \text { Straight street } \\
- & \text { Lower cul-de-sac and good } \\
\text { connectivity }\end{array}$ \\
\hline D-type & & $\begin{array}{ll}\text { - } & \begin{array}{l}\text { Developed within last the } 20 \text { years } \\
\text { (outer suburban) }\end{array} \\
\text { - } & \text { Regular and grid pattern of streets } \\
\text { - } & \text { Small and geometric block size } \\
\text { - } & \text { Relatively equal size blocks } \\
\text { - } & \text { Lowest cul-de-sac density } \\
\text { - } & \text { Highest connectivity }\end{array}$ \\
\hline
\end{tabular}

\section{References}

1. Yang, L.; Ding, C.; Ju, Y.; Yu, B. Driving as a commuting travel mode choice of car owners in urban China: Roles of the built environment. Cities 2021, 112, 103114. [CrossRef]

2. Dèdelè, A.; Miškinytè, A.; Andrušaitytè, S.; Nemaniūtè-Gužienė, J. Dependence between travel distance, individual socioeconomic and health-related characteristics, and the choice of the travel mode: A cross-sectional study for Kaunas, Lithuania. J. Transp. Geogr. 2020, 86, 102762. [CrossRef]

3. Marseglia, G.; Medaglia, C.M.; Ortega, F.A.; Mesa, J.A. Optimal Alignments for Designing Urban Transport Systems: Application to Seville. Sustainability 2019, 11, 5058. [CrossRef]

4. Talen, E.; Koschinsky, J. The Walkable Neighborhood: A Literature Review. Int. J. Sustain. Land Use Urban Plan. $2013,1,42-63$. [CrossRef]

5. Forsyth, A. What is a walkable place? The walkability debate in urban design. Urban Des. Int. 2015, 20, 274-292. [CrossRef] 
6. Soltani, A. Social and urban form determinants of vehicle ownership; evidence from a developing country. Transp. Res. Part A Policy Pr. 2017, 96, 90-100. [CrossRef]

7. Doyle, S.; Kelly-Schwartz, A.; Schlossberg, M.; Stockard, J. Active Community Environments and Health: The Relationship of Walkable and Safe Communities to Individual Health. J. Am. Plan. Assoc. 2006, 72, 19-31. [CrossRef]

8. Durand, C.P.; Andalib, M.; Dunton, G.F.; Wolch, J.; Pentz, M.A. A systematic review of built environment factors related to physical activity and obesity risk: Implications for smart growth urban planning. Obes. Rev. 2011, 12, e173-e182. [CrossRef]

9. Yang, Y. A dynamic framework on travel mode choice focusing on utilitarian walking based on the integration of current knowledge. J. Transp. Health 2016, 3, 336-345. [CrossRef]

10. Leyden, K.M. Social Capital and the Built Environment: The Importance of Walkable Neighborhoods. Am. J. Public Health 2003, 93, 1546-1551. [CrossRef]

11. Mokhtarian, P.L.; Salomon, I.; Redmond, L.S. Understanding the demand for travel: It's not purely 'derived'. Innov. Eur. J. Soc. Sci. Res. 2001, 14, 355-380. [CrossRef]

12. Mokhtarian, P.L.; Salomon, I. How derived is the demand for travel? Some conceptual and measurement considerations. Transp. Res. Part A Policy Pr. 2001, 35, 695-719. [CrossRef]

13. Cao, X.; Mokhtarian, P.L.; Handy, S.L. No particular place to go: An empirical analysis of travel for the sake of travel. Environ. Behav. 2009, 41, 233-257.

14. Papon, F.; Meissonnier, J. Mind your travel! Motivation, time use, and intent: Three factors of travel to be investigated. In Proceedings of the 13th World Conference on Transport Research, Rio de Janeiro, Brazil, 15-18 July 2013.

15. Kang, B.; Moudon, A.V.; Hurvitz, P.M.; Saelens, B.E. Differences in behavior, time, location, and built environment between objectively measured utilitarian and recreational walking. Transp. Res. Part D Transp. Environ. 2017, 57, 185-194. [CrossRef] [PubMed]

16. Mirzaei, E.; Kheyroddin, R.; Behzadfar, M.; Mignot, D. Utilitarian and hedonic walking: Examining the impact of the built environment on walking behavior. Eur. Transp. Res. Rev. 2018, 10, 20. [CrossRef]

17. Kang, B.; Moudon, A.V.; Hurvitz, P.M.; Reichley, L.; Saelens, B.E. Walking objectively measured: Classifying accelerometer data with GPS and travel diaries. Med. Sci. Sports Exerc. 2013, 45, 1419-1428. [CrossRef] [PubMed]

18. Heath, G.W.; Brownson, R.C.; Kruger, J.; Miles, R.; Powell, K.E.; Ramsey, L.T. The Effectiveness of Urban Design and Land Use and Transport Policies and Practices to Increase Physical Activity: A Systematic Review. J. Phys. Act. Health 2006, 3, S55-S76. [CrossRef]

19. Saelens, B.E.; Handy, S.L. Built environment correlates of walking: A review. Med. Sci. Sports Exerc. 2008, 40, S550-S566. [CrossRef]

20. Sugiyama, T.; Neuhaus, M.; Cole, R.; Giles-Corti, B.; Owen, N. Destination and route attributes associated with adults' walking: A review. Med. Sci. Sports Exerc. 2012, 44, 1275-1286. [CrossRef] [PubMed]

21. Jones, P.M. Destination choice and travel attributes. In Determinants of Travel Choice; Hensher, D., Dalvi, Q., Eds.; Saxon House: Farnborough, UK, 1978; pp. 266-311.

22. Hupkes, G. The law of constant travel time and trip-rates. Futures 1982, 14, 38-46. [CrossRef]

23. Gripsrud, M.; Hjorthol, R. Working on the train: From 'dead time' to productive and vital time. Transportation 2012, 39, 941-956. [CrossRef]

24. Redmond, L.S.; Mokhtarian, P.L. The positive utility of the commute: Modeling ideal commute time and relative desired commute amount. Transportation 2001, 28, 179-205. [CrossRef]

25. Parkany, E.; Du, J.; Aultman-Hall, L.; Gallagher, R. Modeling Stated and Revealed Route Choice: Consideration of Consistency, Diversion, and Attitudinal Variables. Transp. Res. Rec. J. Transp. Res. Board 2006, 1985, 29-39. [CrossRef]

26. Milakis, D.; van Wee, B. "For me it is always like half an hour": Exploring the acceptable travel time concept in the US and European contexts. Transp. Policy 2018, 64, 113-122. [CrossRef]

27. Mokhtarian, P.L.; Salomon, I.; Singer, M.E. What Moves Us? An Interdisciplinary Exploration of Reasons for Traveling. Transp. Rev. 2015, 35, 250-274. [CrossRef]

28. Russell, M.; Mokhtarian, P. How real is a reported desire to travel for its own sake? Exploring the 'teleportation' concept in travel behaviour research. Transp. 2014, 42, 333-345. [CrossRef]

29. Ewing, R.; Cervero, R. Travel and the built environment: A meta-analysis. J. Am. Plan. Assoc. 2010, 76, 265-294. [CrossRef]

30. Cervero, R. Mixed land-uses and commuting: Evidence from the American Housing Survey. Transp. Res. Part A Policy Pr. 1996, 30, 361-377. [CrossRef]

31. Cervero, R. Built environments and mode choice: Toward a normative framework. Transp. Res. Part D Transp. Environ. 2002, 7, 265-284. [CrossRef]

32. Milakis, D.; Vlastos, T.; Barbopoulos, N. Relationships between urban form and travel behaviour in Athens, Greece. A comparison with Western European and North American results. Eur. J. Transp. Infrastruct. Res. 2008, 8, 3. [CrossRef]

33. Moilanen, M. Matching and settlement patterns: The case of Norway. Pap. Reg. Sci. 2009, 89, 607-623. [CrossRef]

34. Sandow, E. Commuting behaviour in sparsely populated areas: Evidence from northern Sweden. J. Transp. Geogr. 2008, 16, 14-27. [CrossRef]

35. Yang, J.; Shen, Q.; Shen, J.; He, C. Transport Impacts of Clustered Development in Beijing: Compact Development versus Overconcentration. Urban Stud. 2011, 49, 1315-1331. [CrossRef] 
36. Soltani, A.; Etminani Ghasrodashti, R. The impact of urban density on car dependency, a case study of three residential districts of region 1, Shiraz. J. Urban-Reg. Stud. Res. 2010, 5, 139-154.

37. Munshi, T. Built environment and mode choice relationship for commute travel in the city of Rajkot, India. Transp. Res. Part D Transp. Environ. 2016, 44, 239-253. [CrossRef]

38. Zhao, P.; Lu, B. Managing urban growth to reduce motorised travel in Beijing: One method of creating a low-carbon city. $J$. Environ. Plan. Manag. 2011, 54, 959-977. [CrossRef]

39. Sun, B.; Ermagun, A.; Dan, B. Built environmental impacts on commuting mode choice and distance: Evidence from Shanghai. Transp. Res. Part D Transp. Environ. 2017, 52, 441-453. [CrossRef]

40. Ma, J.; Liu, Z.; Chai, Y. The impact of urban form on CO2 emission from work and non-work trips: The case of Beijing, China. Habitat Int. 2015, 47, 1-10. [CrossRef]

41. Zhao, C.; Nielsen, T.A.S.; Olafsson, A.S.; Carstensen, T.A.; Meng, X. Urban form, demographic and socio-economic correlates of walking, cycling, and e-biking: Evidence from eight neighborhoods in Beijing. Transp. Policy 2018, 64, 102-112. [CrossRef]

42. Shirgaokar, M. Expanding cities and vehicle use in India: Differing impacts of built environment factors on scooter and car use in Mumbai. Urban Stud. 2016, 53, 3296-3316. [CrossRef]

43. Etminani-Ghasrodashti, R.; Ardeshiri, M. The impacts of built environment on home-based work and non-work trips: An empirical study from Iran. Transp. Res. Part A Policy Pr. 2016, 85, 196-207. [CrossRef]

44. Frank, L.D.; Pivo, G. Impacts of mixed use and density on utilization of three modes of travel: Single-occupant vehicle, transit and walking. Transp. Res. Rec. 1994, 1466, 44-52.

45. Zhang, M. The Role of Land Use in Travel Mode Choice: Evidence from Boston and Hong Kong. J. Am. Plan. Assoc. 2004, 70, 344-360. [CrossRef]

46. Kitamura, R.; Fujii, S.; Pas, E.I. Time-use data, analysis and modeling: Toward the next generation of transportation planning methodologies. Transp. Policy 1997, 4, 225-235. [CrossRef]

47. Soltani, A.; Allan, A. Analyzing the Impacts of Microscale Urban Attributes on Travel: Evidence from Suburban Adelaide, Australia. J. Urban Plan. Dev. 2006, 132, 132-137. [CrossRef]

48. Zhao, P. The Impact of the Built Environment on Individual Workers' Commuting Behavior in Beijing. Int. J. Sustain. Transp. 2013, 7, 389-415. [CrossRef]

49. Boarnet, M.G.; Nesamani, K.S.; Smith, C.S. Comparing the influence of land use on nonwork trip generation and vehicle distance traveled: An analysis using travel diary data. In Proceedings of the 83rd Annual Meeting of the Transportation Research Board, Washington, DC, USA, 11-15 January 2004; pp. 1-13.

50. Pushkar, A.O.; Hollingworth, B.J.; Miller, E.J. A multivariate regression model for estimating greenhouse gas emissions from alternative neighborhood designs. In Proceedings of the 79th Annual Meeting of the Transportation Research Board, Washington, DC, USA, 14-15 January 2000.

51. Munshi, T.; Zuidgeest, M.; Brussel, M.; Van Maarseveen, M. Logistic regression and cellular automata-based modelling of retail, commercial and residential development in the city of Ahmedabad, India. Cities 2014, 39, 68-86. [CrossRef]

52. Feng, J.; Dijst, M.; Wissink, B.; Prillwitz, J. Understanding Mode Choice in the Chinese Context: The Case of Nanjing Metropolitan Area. Tijdschr. Econ. Soc. Geogr. 2014, 105, 315-330. [CrossRef]

53. Ding, C.; Wang, D.; Liu, C.; Zhang, Y.; Yang, J. Exploring the influence of built environment on travel mode choice considering the mediating effects of car ownership and travel distance. Transp. Res. Part A Policy Pr. 2017, 100, 65-80. [CrossRef]

54. Hanly, M.; Dargay, J. Land Use and Mobility. In Proceedings of the 10th World Conference on Transport Research, Istanbul, Turkey, 4-8 July 2004.

55. Li, J.; Lo, K.; Guo, M. Do Socio-Economic Characteristics Affect Travel Behavior? A Comparative Study of Low-Carbon and Non-Low-Carbon Shopping Travel in Shenyang City, China. Int. J. Environ. Res. Public Health 2018, 15, 1346. [CrossRef]

56. Schwanen, T.; Dijst, M.; Dieleman, F.M. Leisure trips of senior citizens: Determinants of modal choice. Tijdschr. voor Econ. en Soc. Geogr. 2001, 92, 347-360. [CrossRef]

57. Manoj, M.; Verma, A. Effect of built environment measures on trip distance and mode choice decision of non-workers from a city of a developing country, India. Transp. Res. Part D Transp. Environ. 2016, 46, 351-364. [CrossRef]

58. Mitra, R. Independent Mobility and Mode Choice for School Transportation: A Review and Framework for Future Research. Transp. Rev. 2013, 33, 21-43. [CrossRef]

59. Heinen, E.; Van Wee, B.; Maat, K. Commuting by Bicycle: An Overview of the Literature. Transp. Rev. 2010, 30, 59-96. [CrossRef]

60. Handy, S.L.; Van Wee, B.; Kroesen, M. Promoting Cycling for Transport: Research Needs and Challenges. Transp. Rev. 2014, 34, 4-24. [CrossRef]

61. Fraser, S.D.; Lock, K. Cycling for transport and public health: A systematic review of the effect of the environment on cycling. Eur. J. Public Health 2010, 21, 738-743. [CrossRef] [PubMed]

62. Stern, P.C.; Dietz, T.; Abel, T.; Guagnano, G.A.; Kalof, L. A value-belief-norm theory of support for social movements: The case of environmentalism. Human Ecol. Rev. 1999, 6, 81-97.

63. Ajzen, I. The theory of planned behavior. Organ. Behav. Hum. Decis. Process. 1991, 50, 179-211. [CrossRef]

64. Kitamura, R. Life-style and travel demand. Transportation 2009, 36, 679-710. [CrossRef] 
65. Salomon, I.; Ben-Akiva, M. The Use of the Life-Style Concept in Travel Demand Models. Environ. Plan. A Econ. Space 1983, 15, 623-638. [CrossRef]

66. Van Acker, V.; Mokhtarian, P.L.; Witlox, F. Car availability explained by the structural relationships between lifestyles, residential location, and underlying residential and travel attitudes. Transp. Policy 2014, 35, 88-99. [CrossRef]

67. Van Acker, V. Spatial and social variations in travel behaviour: Incorporating lifestyles and attitudes into travel behaviour-land use interaction research. Ph.D. Thesis, Ghent University, Ghent, Belgium, January 2010.

68. Inoue, S.; Ohya, Y.; Odagiri, Y.; Takamiya, T.; Ishii, K.; Kitabayashi, M.; Suijo, K.; Sallis, J.F.; Shimomitsu, T. Association between Perceived Neighborhood Environment and Walking among Adults in 4 Cities in Japan. J. Epidemiol. 2010, 20, 277-286. [CrossRef]

69. Sugiyama, T.; Cerin, E.; Owen, N.; Oyeyemi, A.L.; Conway, T.L.; Van Dyck, D.; Schipperijn, J.; Macfarlane, D.J.; Salvo, D.; Reis, R.S.; et al. Perceived neighbourhood environmental attributes associated with adults' recreational walking: IPEN Adult study in 12 countries. Health Place 2014, 28, 22-30. [CrossRef]

70. Li, S.; Zhao, P.; Zhang, H.; Quan, J. Walking behavior in the old downtown Beijing: The impact of perceptions and attitudes and social variations. Transp. Policy 2019, 73, 1-11. [CrossRef]

71. Ajzen, I. The theory of planned behaviour: Reactions and reflections. Psychol. Health 2011, 26, 1113-1127. [CrossRef] [PubMed]

72. Simon, H.; Smith, A.J.; Thompson, C.B. Modern organization theories. Adv. Manag. 1950, 15, $2-4$.

73. Pred, A. Behavior and Location: Foundations for a Geographic and Dynamic Location Theory. Part I; The Royal University of Lund: Lund, Sweden, 1967.

74. Isfahan Municipality Official Website. Available online: http:/ / new.isfahan.ir $/$ Index.aspx?tempname=Isfahan95\&lang=1\&sub=0 (accessed on 11 March 2017).

75. Cao, X.; Handy, S.L.; Mokhtarian, P.L. The Influences of the Built Environment and Residential Self-Selection on Pedestrian Behavior: Evidence from Austin, TX. Transportation 2006, 33, 1-20. [CrossRef]

76. Cao, X.; Mokhtarian, P.L.; Handy, S.L. The relationship between the built environment and nonwork travel: A case study of Northern California. Transp. Res. Part A Policy Pr. 2009, 43, 548-559. [CrossRef]

77. Pan, H.; Shen, Q.; Zhang, M. Influence of Urban Form on Travel Behaviour in Four Neighbourhoods of Shanghai. Urban Stud. 2009, 46, 275-294. [CrossRef]

78. Israel, G.D. Determining Sample Size. Institute of Food and Agricultural Sciences (IFAS); PEOD-6; University of Florida: Gainesville, FL, USA, 2013; pp. 1-5.

79. Havlíčková, D.; Zámečník, P. Considering Habit in Research on Travel Mode Choice: A Literature Review with a Two-Level Methodology. Trans. Transp. Sci. 2020, 11, 18-32. [CrossRef]

80. Ouellette, J.A.; Wood, W. Habit and intention in everyday life: The multiple processes by which past behavior predicts future behavior. Psychol. Bull. 1998, 124, 54-74. [CrossRef]

81. Naghshe-Jahan Pars Consultants. The Revision of Detailed Plan of Isfahan, Isfahan Municipality; Internal Report; Deputy of Architecture And Urban Planning: Isfahan, Iran, 2012.

82. Forsyth, A.; Hearst, M.; Oakes, J.M.; Schmitz, K.H. Design and Destinations: Factors Influencing Walking and Total Physical Activity. Urban Stud. 2008, 45, 1973-1996. [CrossRef]

83. Bennasar-Veny, M.; Yañez, A.M.; Pericas, J.; Ballester, L.; Fernandez-Dominguez, J.C.; Tauler, P.; Aguilo, A. Cluster Analysis of Health-Related Lifestyles in University Students. Int. J. Environ. Res. Public Health 2020, 17, 1776. [CrossRef] [PubMed]

84. Ory, D.T.; Mokhtarian, P.L. Modeling the structural relationships among short-distance travel amounts, perceptions, affections, and desires. Transp. Res. Part A Policy Pr. 2009, 43, 26-43. [CrossRef]

85. Deutsch, K.; Yoon, S.Y.; Goulias, K. Modeling travel behavior and sense of place using a structural equation model. J. Transp. Geogr. 2013, 28, 155-163. [CrossRef]

86. Stedman, R.C. Is It Really Just a Social Construction?: The Contribution of the Physical Environment to Sense of Place. Soc. Nat. Resour. 2003, 16, 671-685. [CrossRef]

87. Tan, L.; Ma, C.; Xu, X.; Xu, J. Choice Behavior of Autonomous Vehicles Based on Logistic Models. Sustainability 2019, $12,54$. [CrossRef]

88. Boulange, C.; Gunn, L.; Giles-Corti, B.; Mavoa, S.; Pettit, C.; Badland, H. Examining associations between urban design attributes and transport mode choice for walking, cycling, public transport and private motor vehicle trips. J. Transp. Health 2017, 6, 155-166. [CrossRef]

89. Wang, D. Place, context and activity-travel behavior: Introduction to the special section on geographies of activity-travel behavior. J. Transp. Geogr. 2015, 47, 84-89. [CrossRef]

90. Deutsch, K.; Goulias, K. Exploring Sense-of-Place Attitudes as Indicators of Travel Behavior. Transp. Res. Rec. J. Transp. Res. Board 2010, 2157, 95-102. [CrossRef]

91. Christiansen, L.B.; Cerin, E.; Badland, H.; Kerr, J.; Davey, R.; Troelsen, J.; van Dyck, D.; Mitáš, J.; Schofield, G.; Sugiyama, T.; et al. International comparisons of the associations between objective measures of the built environment and transport-related walking and cycling: IPEN adult study. J. Transp. Health 2016, 3, 467-478. [CrossRef] [PubMed]

92. Boarnet, M.G.; Greenwald, M.; McMillan, T.E. Walking, urban design, and health: Toward a cost-benefit analysis framework. J. Plan. Educ. Res. 2008, 27, 341-358. [CrossRef]

93. Frank, L.D.; Engelke, P. Multiple Impacts of the Built Environment on Public Health: Walkable Places and the Exposure to Air Pollution. Int. Reg. Sci. Rev. 2005, 28, 193-216. [CrossRef] 
94. Steg, L. Car use: Lust and must. Instrumental, symbolic and affective motives for car use. Transp. Res. A Policy Pract. 2005, 39, 147-162.

95. Triandis, H.C. Interpersonal Behavior; Brooks/Cole: Monterey, CA, USA, 1977.

96. Triandis, H.C. Values, attitudes, and interpersonal behavior. In Nebraska Symposium of Motivation, 1980: Cognitive Processes; Howe, H.E., Jr., Page, M., Eds.; University of Nebraska Press: Lincoln, NE, USA, 1980; Volume 27, pp. 195-259. 